\title{
Adaptation strategies for people: mitigating climate-change-related risks in low-income and informal urban communities through co-production
}

\author{
Soledad Garcia Ferrari, Katharina Kaesehage, \\ Stephanie Crane De Narvaez and Amelia A. Bain
}

Abstract: Traditional top-down strategies to reduce climate-change-related risks have often failed to produce tangible results in vulnerable urban areas of the Global South. Approaches based on the co-production of adaptation solutions between diverse stakeholders offer promising alternative strategies. This contribution draws on our experiences in growing informal and low-income urban areas in two Latin American cities, Medellín (Colombia) and Puebla (Mexico). These communities lack adequate access to clean water and are exposed to risks related to increasingly frequent high-intensity rainfall events, making water management a key consideration for risk reduction. However, the factors driving insufficient water access and the perceptions of risks vary in each location, demonstrating the need for context-specific solutions. We explore how increasing community agency and co-creating knowledge for risk management between diverse stakeholders at a range of geographical scales can contribute to redressing existing social and environmental injustices, by identifying, implementing, and scaling up technically appropriate and culturally sustainable solutions aimed at reducing climate-change-related risks.

Keywords: Climate change, resilience, mitigation, adaptation, informal urban communities, co-production, integrated risk management, integrated water management, community agency.

Notes on the authors: see end of the article.

(C) The author(s) 2021. This is an open access article licensed under a

Creative Commons Attribution-NonCommercial-NoDerivs 4.0 Unported License 


\section{Introduction}

In growing cities, issues of vulnerability, socio-spatial segregation, and inequality are aggravated by risks brought forth by climate change in communities that are exposed to a range of social, economic, and environmental strains. The challenges that such climate-change-impacted cities face require context-specific solutions that respond to the needs of the most vulnerable. Recent research demonstrates that informal urban communities in highly densified urban areas or in rural-urban peripheries especially struggle to adapt to climate-change-related risks in sustainable, affordable, and appropriate ways (Satterthwaite et al. 2017). In the context of the Global South, and Latin America in particular, approaches to reducing vulnerability through risk management and climate change adaptation are typically based around top-down decision-making, coupled with a lack of institutional capacities to address the accumulation of risks within low-income and informal settlements. The implementation of such 'traditional' forms of governance has yielded limited success in creating sustainable solutions in these communities. Appropriate mitigation and adaptation measures, including necessary infrastructure solutions, are difficult to implement due to resource implications, but also due to complex socio-economic, political, and institutional processes, particularly around low-income and informal settlements.

Recently, 'smart' technologies have been implemented by city authorities with the aim of creating more integrated, habitable, and sustainable cities through the application of intelligent, efficient technological strategies at a large urban scale (Barrionuevo et al. 2012). A wide range of 'smart city' strategies and programmes have been applied: for example, in urban transportation systems to monitor and optimise mobility; in resource management systems to optimise resource use (for example, energy, water, waste); and in governance to facilitate data management, improve institutional transparency and communication strategies, and promote citizen participation and inclusion, through a myriad of digital platforms. However, these strategies have typically been developed and implemented in a top-down manner and frequently omit a consideration of the needs of, potential impact on, or benefit to people living in informal or vulnerable communities (Greenfield 2013, Hollands 2015, Kitchin 2014). How such 'innovative' technological approaches could be leveraged to address climate-change-related risks in an inclusive way, to deliver a tangible reduction in vulnerability, is poorly understood.

Recognising the need for greater community ownership of risk reduction initiatives, theoretical discourses in the field of risk management have gradually evolved from a recognition of the importance of community-based and local-level risk management (e.g., Lavell 2003, Maskrey, 1984, 2011), to the current focus on interlinkages between building resilience and sustainable development (e.g., beginning with Wilches-Chaux, 1993), and the importance of integrated risk management and citizen participation 
(e.g., Sendai Framework (UNISDR 2015) and Sustainable Development Goals (UN General Assembly 2015)). These developments have begun to permeate into governance. For example, in Colombia, both the national Constitution (Asamblea Nacional Constituyente 2021) and the Medellín 2020-2023 Municipal Development Plan (Alcaldía de Medellín 2020) place an emphasis on citizen participation, despite varying degrees of success in implementation. In Mexico, citizen participation is promoted by the national Constitution (Cámara de Diputados 2021), but national civil protection legislation has been criticised for being too reactive and lacking integration across sectors and government levels (Alcántara-Ayala et al. 2019). Mexico City is leading the way in respect of integrated risk management in the country, having passed progressive legislation (PAOT 2019) creating new institutions and programmes that are intended to improve coordination between city and local-level governments, and promote a culture of risk prevention, citizen participation, and co-responsibility (Garcia Ferrari et al., under review).

In this context, researchers and policymakers are requesting guidance and tools that consider not only the scientific understanding of risks on a local level, but also the capacity of citizens and community groups who live in impacted areas to adjust to and cope with the consequences of climate change (Davies et al. 2009, IPCC 2007, Pelling 2011). Key issues that impact local capacity to adapt to climate change include (i) differences in perceptions of risk and potential infrastructure solutions among stakeholders (from community to government); (ii) the consideration of diverse social, economic, and environmental issues, such as the different types of knowledge (formal/ informal, technical/social) required to interact in defining solutions and policy implementation strategies; (iii) a dearth of financial resources; and (iv) differences in stakeholder's needs and power balance. A thorough understanding of these factors requires knowledge identification, knowledge development, and compromise at a range of power levels and across diverse actors, aimed towards the co-production of climate change adaptation strategies and sustainable infrastructure (UN-Habitat 2011). In recent years, such co-production approaches, originally developed in the public services sector, have been successfully applied to risk management (e.g., AguilarBarajas et al. 2019, Fraser 2017, López Meneses \& Cañadas 2018). These approaches consider that complex problems, such as those related to extreme climate events or water justice in the context of an aggravating climate emergency, represent opportunities for solutions to be co-produced by a range of relevant stakeholders, such as community members, governments, non-governmental organisations (NGOs), and technical and/or scientific experts (Aguilar-Barajas et al. 2019). The co-production process is based on multifaceted knowledge sharing - through a 'dialogue of knowledges' - towards building short- and long-term capacity to maintain or rapidly return to the desired functions of the city in the face of a crisis (ibid.). 
Our ongoing research in the cities of Medellín (Colombia) and Puebla (Mexico) is exploring the potential for co-produced mitigation and adaptation solutions to reduce climate-change-related risks in vulnerable informal and low-income urban areas. In particular, our research has highlighted integrated water management as a key concern in these areas, due to inadequate access to clean water, coupled with risks associated with increasingly frequent high-intensity rainfall events. As the factors driving insufficient water access and the nature and perceptions of risks vary in each location, our research seeks to identify context-specific solutions that contribute to reducing structural inequalities and risk, increasing social equity, and adapting to climate change. Further, our research is exploring how these solutions can be upscaled from the community level to a wider city context, leveraging community-informed 'smart' technologies to more effectively monitor and mitigate risks. Our approach has been rooted in understanding opportunities for co-development of 'actions' in close collaboration with local private and public sector stakeholders, to integrate multi-scale feedback-rich systems for risk monitoring and adaptation. The overarching goal of this work is to develop transdisciplinary knowledge and build capacity for policy implementation around issues of water governance, water security, integrated risk management, and co-produced water and risk management infrastructure.

This paper draws on the lessons from these transdisciplinary experiences, providing evidence on how bottom-up solutions can contribute to solving not only water access issues, but also to reducing vulnerability to climate-change-related risks and increasing the well-being of communities inhabiting informal and low-income urban areas. In this contribution we explore the following research questions:

1. How can stakeholder perceptions of climate-change-related risks in vulnerable informal and/or low-income urban areas help to identify priorities for risk mitigation and adaptation?

2. How can a 'dialogue of knowledges' between stakeholders help to co-create technically appropriate and culturally accepted water management strategies for risk mitigation and adaptation?

3. How can alternative approaches rooted in co-production between diverse stakeholders contribute to building resilience on a local level for integrated risk management via 'smart' technologies?

The following section presents an overview of key concepts serving as the theoretical framework upon which we base our analysis of case studies in Medellín and Puebla, addressing the gap between top-down governance that has failed to provide meaningful change and the need for effective solutions to manage climatechange-related risks at the local level. We first review the causes of vulnerability to climate-change-related risks in growing urban areas and the concepts of building 
resilience and adaptation. We then summarise the role of co-production approaches to build adaptive capacity to climate-change-related risks. Finally, we explore the potential for co-created 'smart city' solutions to increase adaptive capacity in vulnerable urban communities. In Section 3, we then outline the scope and focus of our previous and current research in Medellín and Puebla. Finally, we discuss the significance of our findings in relation to the outlined theoretical framework in Section 4.

\section{Theoretical framework}

\subsection{Climate change vulnerability and adaptation in growing low-income and informal urban areas}

Increasing urbanisation has driven the growth of low-income and informal communities in areas exposed to a range of environmental risks and climate-change-related hazards. The United Nations currently estimates that over one billion people globally live in vulnerable informal settlements, and this number increased between 2014 and 2018 (United Nations 2021). These complex areas are often affected by weak governance and limited financial capacity for research, policy development, and action. Low-income and self-built urban areas may also be shaped by development patterns that create new risks or exacerbate existing risks. These factors result in growing vulnerable populations living on land that is unsafe, under-serviced, and insufficiently safeguarded by planning policies (Baker 2013). Key issues that affect vulnerability of the urban poor include inadequate basic services (that is, water, sanitation, proper drainage, reliable transport, roads, or health services), as well as tenure insecurity, poor financial security, social networks, and ad hoc adaptation to climate change and environmental hazards (ibid.). These vulnerable communities are increasingly exposed to climate-change-related risks, such as drought or high-intensity rainfall events triggering flash flooding and landslides, yet are often least able to cope with the associated impacts because of a limited capacity to adapt (Davies et al. 2009, Hardoy \& Romero Lankao 2011). Furthermore, weak governance and a lack of policy development contribute to shifting the focus of public sector authorities to the most pressing problems impacting these communities via short-term programmes (UN-Habitat 2011) that tend to focus on infrastructure, resources, or health challenges in isolation, and fail to integrate local human resources, knowledge, and adaptation strategies. Such developments are especially problematic in Latin American cities, which have experienced sharp urban growth and where IPCC (Intergovernmental Panel on Climate Change) scenarios forecast increasingly common extreme climate events (Magrin et al. 2014). 
In this context, building resilience requires new strategic approaches that integrate communities into decision-making, as those directly affected by climate-changerelated risks 'have the best practical knowledge' because these phenomena affect their lives and livelihoods on a regular basis (Anderson \& Holcombe 2013). In addition, given the heterogeneous and unequal impacts of risk in different geographic and demographic contexts, it is critical to understand risk accumulation patterns linked to varying degrees of hazard, exposure, vulnerability, and resilience (Maskrey 2011). Within this approach, vulnerability not only refers to the extent to which a community is exposed to severe climatic events or trends, and the effects on lives and the environment, but also how these events affect the ability of communities to adapt to shocks (CARE 2014). Linking the notions of vulnerability and climate change adaptation is the concept of adaptive capacity (or adaptation capacity), defined by the IPCC as: 'The ability of a system to adjust to climate change (including climate variability and extremes), to moderate potential damages, to take advantage of opportunities, or to cope with the consequences' (IPCC 2007: 21). Approaching vulnerability from an adaptive capacity perspective can help to better examine the 'factors that influence a system's ability to modify behaviour to better cope with external pressures, such as climate change' (Ekström et al. 2013). Risk management strategies that integrate the adaptive capacity of citizens and community groups living in urban areas prone to climate-change-related risks, especially in low-income and informal settlements, are therefore critical (Satterthwaite et al. 2017).

Pelling (2011) details a three-level framework considering adaptation as an opportunity for systemic reform and gains in terms of well-being and rights, rather than an exercise in preservation of the status quo. Pelling defines the three levels of adaptation as: (1) resilience, enabling stability in the face of shocks and a return to the status quo; (2) transition, enabling incremental social change and the exercise of existing rights; and (3) transformation, empowering communities with new rights claims and achieving radical change in political regimes. This framework facilitates understanding the social, cultural, and political pathways through which adaptation may be achieved, and frames adaptation as a means of redressing existing social and environmental injustices.

Addressing, minimising, monitoring, and adapting to risks also encounters challenges related to differences in the perception of risk among stakeholders (for example, between informal urban communities and public sector institutions), as well as a lack of effective options for communicating formal, informal, professional, and lay knowledge on how to mitigate and adapt to risk, in addition to a lack of clarity on the responsibilities and roles of stakeholders (Etkin \& Ho 2007). Addressing these challenges in relation to climate change requires an integrated approach aimed at empowering informal urban communities in observing their environment, understanding 
potential strategies for risk management, and leveraging their knowledge to implement suitable adaptation strategies that respond to the specific economic, social, urban, and environmental patterns (Smith et al. 2020a), and thus contribute to moving beyond resilience towards adaptive transformation (Pelling 2011).

\subsection{Co-production approaches to build adaptive capacity to climate-change-related risks}

In the Global South, co-production initiatives have been implemented to address inadequate community service provision, and to bridge the gap between top-down public management systems and the often disadvantaged citizens accessing these services (Mitlin \& Bartlett 2018). Such co-production processes have been shown to strengthen community capacities, empowering low-income and informal communities to collaborate around their needs, contest power, and negotiate with public sector authorities (Allen et al. 2017, Mitlin 2008, Mitlin \& Bartlett 2018, Watson 2014). Following on from experiences with community-based disaster risk management during the 1980s and 1990s that included explorations of co-production, this approach is beginning to gain traction in the field of risk management (e.g., Aguilar-Barajas et al. 2019, Anderson \& Holcombe 2013, Fraser 2017, López Meneses \& Cañadas 2018, Moser \& Stein 2011). These co-production approaches recognise that building resilience requires solutions that are designed and implemented based on knowledge held within different stakeholder groups (e.g., Aguilar-Barajas et al. 2019).

Within this alternative approach, the co-production of risk management can be achieved through the implementation of a 'dialogue of knowledges' between diverse stakeholders in a specific territory, by creating a space for knowledge exchange and conflict resolution to allow negotiated agreements and solutions to be reached (e.g., Garcia Ferrari et al. 2021, Smith et al. 2020a, 2020b, 2021). This dialogue entails placing local knowledge on a level platform with technical and scientific knowledge, allowing actors such as community representatives, government institutions, NGOs, the private sector, and academia to collaborate and co-design strategies for risk management that are culturally and technically appropriate and accepted, and therefore sustainable. This approach is especially valuable where conflicts exist between the interests of the community and those of other stakeholders, which is particularly common in informal and low-income communities, and offers promising opportunities for reducing vulnerability to climate-change-related risks.

Co-production also constitutes a method of questioning urban production processes that create social injustice and inequality (Maguire \& Cartwright 2008, Stevenson \& Petrescu 2016), and moves beyond concepts of user involvement and participative design to directly engage stakeholders on the principle of equal 
partnership (Stevenson \& Petrescu 2016). This approach, where stakeholders bring a diverse range of skills and knowledge based on lived and professional experience, bridges the gap between those who produce the built environment and those who use it (Allen et al. 2017, Stevenson \& Petrescu 2016). In line with Pelling's framework described above, co-production represents a means of altering existing relationships between actors and modifying ongoing practices, empowering communities with the notion of urban citizenship (Mitlin \& Bartlett 2018), and opening up opportunities for adaptive transformation through negotiated, agreed action.

Addressing local resilience within the approach of co-production and from a perspective that understands multidimensional risk requires considering three essential elements (Brugnach et al. 2017):

(i) Scale: Addressing risk at the local scale and at the community level is particularly important as 'local risk management represents the best - and often the onlyoption for direct action on the most specific conditions of vulnerability, acting on the capacities and resilience built through the history and social context of a community' (Durán Vargas 2011). Communities affected by risks tend to know their territory and are better prepared to monitor threats and respond via adaptation strategies. Consequently, risk analysis for different hazards must be evaluated together with socioeconomic processes at the local level, in order to better understand vulnerability (Maskrey 1989).

(ii) Knowledge: The effectiveness of risk mitigation depends on the integration of multifaceted knowledge, built collaboratively between actors (Hallegatte et al. 2018). This approach equates local knowledge with scientific and institutional knowledge. The co-production of knowledge to identify relevant solutions at the local level has been identified as key for sustainable community development processes and must be implemented through a grassroots approach (Ekanayake 1990). Further, this element strengthens the opportunity for a 'dialogue of knowledges', in which community knowledge takes a significant role in the negotiation of mitigation strategies, and different types of experience are strengthened and complemented (Smith et al. 2020a).

(iii) Power: Vulnerable groups must be empowered to influence decision-making at the local level, using community knowledge to respond to risks, assuming an active and participatory role in risk assessment, mitigation planning, capacity building, and monitoring (Pandey \& Okazaki, n.d.).

Overall, the literature suggests that co-production strategies implemented as part of community-based and local-level risk reduction initiatives should aim to achieve the following objectives: 
a) Allow communities to collaborate around their needs, contest power, and negotiate (e.g., Allen et al. 2017, Mitlin 2008, Mitlin \& Bartlett 2018, Watson 2014).

b) Allow communities to unlock the necessary political and economic resources to reduce their own vulnerability and manage risk (Maskrey, 1984, 2011).

c) Allow a restructuring of relations between civil society and the state (Maskrey 2011), redressing power imbalances and antagonisms (Mitlin \& Bartlett 2018), bridging the gap between those who produce the built environment and those who use it (Allen et al. 2017, Stevenson \& Petrescu 2016).

d) Place different knowledge types (for example, traditional, local, technical, academic) on a level platform (e.g., Aguilar-Barajas et al. 2019, Allen et al. 2017, Borquez et al. 2017, Brugnach et al. 2017, Maskrey, 1984, Stevenson \& Petrescu 2016).

e) Ensure the sustainability of agreed mitigation or adaptation solutions by ensuring community acceptability (Maskrey 1984) as well as appropriation by local groups/ organisations (Lavell 2003).

f) Allow upscaling of local-level actions to the regional scale, through partnership with public sector authorities (Maskrey 1984).

g) Ensure equitable inclusion of indigenous people through appropriate collective decision-making, multi-scalar negotiations, blended knowledge, and powersharing structures (Brugnach et al. 2017).

h) Build short- and long-term capacity to maintain or rapidly return to the desired functions of the community in the face of a disturbance by implementing contextspecific, acceptable, and sustainable mitigation and adaptation measures (Aguilar-Barajas et al. 2019).

In this regard, examples of co-production of risk and water management demonstrate that third parties, such as NGOs and academia, play a valuable role in bringing additional knowledge types to supplement that existing in the community, as well as ensuring continuity, through supporting the management and sustainability of medium- and long-term strategies.

\subsection{Increasing adaptive capacity to climate-change-related risks through co-created 'smart' technologies and infrastructure}

Rapid urban growth, coupled with the growing impacts of the climate crisis, has resulted in a global paradigm shift to design innovative and sustainable 'smart city' solutions (via infrastructures and services) to address these intractable problems (Bibri \& Krogstie 2017). Chourabi et al.(2012) argue that 'smart cities' can be conceptualised as an icon of a sustainable and liveable city. However, there is a diversity of 
perspectives, focuses, and scopes for the strategies developed within 'smart city' approaches (see further discussion in Albino et al. 2015 and Chourabi et al. 2012), demonstrating how vague the term 'smart city' remains, both in theory and in practice. Although 'smart cities' is a contested concept that has not found an overall consensus (Angelidou 2014), the notion generally represents a new urban revolution that will successfully replace the industrial era in the organisation of cities, in terms of infrastructure provision (Picon 2015).

In addition, many climate change experts, national politicians, and city leaders have acknowledged 'smart city' infrastructure and solutions as being at the forefront of climate change action in urban contexts (Appleby 2020, Calthorpe 2011, LuqueAyala \& Marvin 2015, Moreno Pires et al. 2017, van der Most et al. 2018, White 2016). Thus, cities have attempted to implement 'smart city' technology to facilitate monitoring of and adaptation to climate change risks, as well as to capture local community knowledge. 'Smart' technology is therefore proposed as a tool to increase resilience and confront challenges from a multi-framework approach, integrating policy, communities, and technologies, based on information and communication (Chourabi et al. 2012, Mustapha et al. 2016). There is also tentative evidence that 'smart' technology should be used as an opportunity to engage with a range of actors and decision-makers at different geographical scales to enable improved responses to specific current and future community needs (Pelton \& Singh 2019).

Within the above context, an understanding of how 'smart' technologies will increase the well-being of the most vulnerable citizens is still lacking, as 'smart city' initiatives tend to be implemented in a top-down manner that does not necessarily consider the needs of or benefit fto people living in low-income and informal urban areas. Critics of typical top-down 'smart city' projects argue that, within the 'triple helix' of government, knowledge production, and industry, citizens are often overlooked in policymaking as they are not seen as equal agents in the construction of resilience and in risk management (de Lange \& de Waal 2013). Alternative 'smart city' approaches to resilience and risk management have therefore been proposed, such as crowdsourcing monitoring data on flooding (e.g., Frigerio et al. 2018), which offer the opportunity for community ownership of risk reduction initiatives through their engagement and empowerment to act on complex collective urban problems. For vulnerable communities to be more resilient to climate change risk, 'smart city' projects must recognise that citizens have to play a central role (ibid.).

Advocates of a 'smart city' approach to supporting urban communities vulnerable to climate change risks argue that providing the means for citizens to leverage technology and recognise a 'smart city's' capacity for effective change empowers citizens to be more resilient and adapt to risk more effectively (Lytras \& Visvizi 2020). However, although previous studies have shown that urban communities can effectively 
minimise, manage, and adapt to environmental risks (Hill \& Martinez-Diaz 2020), these findings are limited to communities that use one specific technology and/or solution, such as renewable energy or a community currency. Research on community adaptation to climate-change-related risks through creating empowerment across geographical scales and a variety of climate change impacts is still lacking.

For vulnerable urban communities, the challenge of adaptation to climate-change-related risks is partly related to the need for more complex informationsharing that integrates feedback-rich systems across multiple actors throughout society. Experiences with 'smart city' technologies have shown that technical knowledge is only one part of the solution. A greater challenge lies in such technologies, as well as the knowledge and communication that they provide and require, being accepted, understood, and legitimised, in order for appropriate courses of action to be identified and implemented to increase resilience. Achieving this technology usage, applicability, and impact, particularly in informal areas, requires a better understanding of the needs and capacities of informal urban communities in relation to climate change risks, and the co-production of adaptive actions between communities and public sector actors (Albino et al. 2015). The challenges faced by the concept of 'smart cities' therefore reflect a need for context-specific solutions and actions, but also offer excellent potential for knowledge upscaling, allowing impact and risk reduction beyond the neighbourhood scale.

\section{Research methodology: co-producing solutions to climate-change-related risks in low-income and informal urban communities in Medellín (Colombia) and Puebla (Mexico)}

Through our work in the cities of Medellín and Puebla, we have developed participatory action research methodologies to understand perceptions of risk and stakeholder priorities in terms of risk management, as well as appropriate and sustainable mitigation and adaptation solutions, in low-income and informal urban areas in Latin America (Table 1). This research led to the identification and pilot testing of coproduced monitoring, mitigation, and adaptation strategies for environmental risks, which are aggravated by climate change. In Medellín, these efforts focused on cocreated action to monitor and mitigate landslide risk in informal neighbourhoods, including 'smart' communication to facilitate knowledge exchange and increase adaptive capacity. In Puebla, the focus was on 'smart' technology for sharing knowledge and adaptation solutions to climate change risks in relation to water management at the urban-rural edge of a growing metropolitan area. In these case studies, the research explored the diverse perceptions of climate-change-related risks 
Table 1. Summary of action-research methodologies applied in the completed research phases in Medellín and Puebla (ongoing work continues in these cities, see text for further details).

\begin{tabular}{|c|c|c|c|}
\hline & SUMMARY OF ACTION-RESEARCH M & ETHODOLOGIES & \\
\hline & Research Phase \& Neighbourhoods & Research Method & Description \\
\hline & Phase 1: 2016-17 & Objective 1: Understand local perceptions of risk & \\
\hline & "Resilience or resistance? Negotiated & Focus groups with residents and community leaders & 2 focus groups (total around 50 participants) \\
\hline & $\begin{array}{l}\text { settlements in Medellin" (see Smith et } \\
\text { al., 2020a; 2020b) }\end{array}$ & $\begin{array}{l}\text { Semi-structured interviews with residents and } \\
\text { community leaders }\end{array}$ & 16 interviews \\
\hline & Initial case study community: Pinares & $\begin{array}{l}\text { Semi-structured interviews with key stakehold ers in } \\
\text { the public sector }\end{array}$ & 6 interviews \\
\hline & & Workshops with third sector actors & \\
\hline & & Objective 2: Pilot participatory monitoring and mitig & gation strategies \\
\hline & & \begin{tabular}{|l|} 
Transect walks and participatory mapping exercise \\
with residents to identify critical mon itoring points
\end{tabular} & \\
\hline & & $\begin{array}{l}\text { Training of community members to record signs of } \\
\text { slope instability using mobile phone photography } \\
\text { and WhatsApp groups }\end{array}$ & $\begin{array}{l}\text { Preparation of a detailed guidance manual, } \\
\text { including monitoring points, frequency of } \\
\text { observations and safety conditions; workshop; and } \\
\text { field walk. }\end{array}$ \\
\hline & & $\begin{array}{l}\text { Regular monitoring of selected critical points by } \\
\text { community members; information reviewed by } \\
\text { academic/technical team }\end{array}$ & $\begin{array}{l}\text { Community-based researchers collected data and } \\
\text { uploaded it to WhatsApp groups during the rainy } \\
\text { season (May-October 2017) }\end{array}$ \\
\hline & & $\begin{array}{l}\text { Technical survey of the area, including land and } \\
\text { housing, to identify potential interventions for } \\
\text { mitigation of landslide risk }\end{array}$ & \\
\hline & & $\begin{array}{l}\text { Training of community members and implementation } \\
\text { of appropriate technical solutions, in collaboration } \\
\text { with architecture and geology/geotechnical research } \\
\text { team experts, to mitigate landslide risk in the } \\
\text { neighbourhood }\end{array}$ & $\begin{array}{l}\text { Mitigation works carried out by the community at } \\
\text { the level of individual households, lanes and } \\
\text { streets, with a focus on benefitting the community } \\
\text { as a whole (September-October 2017) }\end{array}$ \\
\hline & & $\begin{array}{l}\text { Evaluation workshops with the community-based } \\
\text { monitoring team, academic/technical team, and } \\
\text { public and third sector agencies, to assess the } \\
\text { success of the pilot monitoring and mitigation } \\
\text { schemes and aspects to be optimised. }\end{array}$ & 2 workshops (total around 50 participants) \\
\hline & & $\begin{array}{l}\text { Objective 3: Explore the potential for negotiated str } \\
\text { community and public-sector actors }\end{array}$ & rategic lands lide risk management between the \\
\hline 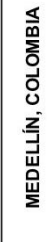 & & $\begin{array}{l}\text { Joint workshops between community } \\
\text { members/leaders, public sector and third sector } \\
\text { actors, to reflect on the project findings and identify } \\
\text { ways forward for, and hind rances to, institutional } \\
\text { mechanisms to facilitate agreement and joint action } \\
\text { between the stakeholders involved in risk } \\
\text { management and mitigation strategy-building and } \\
\text { implementation at different scales }\end{array}$ & $\begin{array}{l}\text { Bi-lateral and multi-stakelhoder (open) meetings; a } \\
\text { multi-stakeholder working group was also set up to } \\
\text { determine a future risk reduction strategy at the } \\
\text { local level, as well as potential larger infrastructure } \\
\text { intervention with possible municipal financing - the } \\
\text { group includes: community representatives; the } \\
\text { municipal Planning Department (DAP); Disaster- } \\
\text { Risk Management Department (DAGRD); Social } \\
\text { Housing Institute (ISVIMED); and the Urban } \\
\text { Development Company (EDU). }\end{array}$ \\
\hline & Phase 2: 2017-19 & Component 1: Understanding local perceptions of $r$ & risk \\
\hline & $\begin{array}{l}\text { "Co-production of landslide risk } \\
\text { management strategies through }\end{array}$ & $\begin{array}{l}\text { Semi-structured interviews with community residents } \\
\text { and leaders }\end{array}$ & $\begin{array}{l}13 \text { interviews in EI Pacífico; } 19 \text { interviews in } \\
\text { Carpinelo } 2\end{array}$ \\
\hline & $\begin{array}{l}\text { development of } \\
\text { community-based infrastructure in Latin } \\
\text { American cities" (see Smith et al., } \\
2020 \text { b; 2021) } \\
\text { Expansion of methodology to two }\end{array}$ & $\begin{array}{l}\text { Semi-structured interviews with government } \\
\text { representatives, NGOs and local academic } \\
\text { institutions }\end{array}$ & $\begin{array}{l}\text { Interviews with: Municipal Planning Department } \\
\text { (DAP); Municipal Disaster Risk Management } \\
\text { Department (DAGRD); Social Housing Institute } \\
\text { (ISVIMED); Urban Development Company (EDU); } \\
\text { NGOs Con-Vivamos and Corporación Montanoa; } \\
\text { Colegio Mayor de Antioquia. }\end{array}$ \\
\hline & additional communities: EI Pacitico & Component 2: Community-based monitoring of lan & idslide risks \\
\hline & 1), Medellín & $\begin{array}{l}\text { Transect walks and participatory mapping workshop } \\
\text { to identify monitoring points in each neighbourhood }\end{array}$ & $\begin{array}{l}5 \text { monitoring points in El Pacífico; } 6 \text { monitoring } \\
\text { points in Carpinelo } 2\end{array}$ \\
\hline & & \begin{tabular}{|l|} 
Training of community volunteers to monitoring \\
critical points using mobile phones
\end{tabular} & $\begin{array}{l}1 \text { workshop in El Pacífico (around } 20 \text { participants); } \\
1 \text { workshop in Carpinelo } 2 \text { (around } 15 \text { participants) }\end{array}$ \\
\hline & & $\begin{array}{l}\text { Regular monitoring of selected critical points by } \\
\text { community members; information reviewed by } \\
\text { academic/technical team }\end{array}$ & $\begin{array}{l}\text { Community-based researchers collected data and } \\
\text { uploaded it to WhatsApp groups during the rainy } \\
\text { season (August-October 2018) }\end{array}$ \\
\hline & & $\begin{array}{l}\text { Workshops for qualitative analysis of photographs, } \\
\text { held with community volunteers, facilitated by the } \\
\text { research teams }\end{array}$ & $\begin{array}{l}2 \text { workshops in El Pacifico (around } 25 \text { participants } \\
\text { in each); } 2 \text { workshops in Carpinelo } 2 \text { (around } 20 \\
\text { participants in each) }\end{array}$ \\
\hline & & $\begin{array}{l}\text { Final evaluation workshops with the community } \\
\text { volunteers, facilitated by the research teams }\end{array}$ & $\begin{array}{l}1 \text { workshop in El Pacífico (around } 25 \text { participants); } \\
1 \text { workshop in Carpinelo } 2 \text { (around } 20 \text { participants) }\end{array}$ \\
\hline & & Component 3: Community-manage d mitigation & \\
\hline & & $\begin{array}{l}\text { Joint identification between community members } \\
\text { and research team of appropriate future strategies } \\
\text { for risk mitigation in each neighbourhood; } \\
\text { Stakeholder mapping. }\end{array}$ & Co-produced mitigation strategy document. \\
\hline & & Component 4: Agreement seeking and strategy bu & uilding \\
\hline & & $\begin{array}{l}\text { Open public meetings (cabildos) held in } 2017 \text { and } \\
2018 \text {, attended by community members and local } \\
\text { government representatives, on the theme of risk } \\
\text { management and integrated neighbourhood } \\
\text { improvement. }\end{array}$ & Attended by over 600 residents. \\
\hline
\end{tabular}




\begin{tabular}{|c|c|c|c|}
\hline \multirow{10}{*}{ 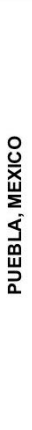 } & \multirow{10}{*}{$\begin{array}{l}\text { Phase 1: } 2019 \\
\text { 'Developing collaborative smart city } \\
\text { solutions to manage adaptation and } \\
\text { monitoring climate change related risks } \\
\text { in Mexico' } \\
\text { San Andrés Cholula }\end{array}$} & \multicolumn{2}{|c|}{ Objective 1: Understand perceptions of climate change-related risks } \\
\hline & & Focus groups with community members & 6 focus groups (around 12 participants in each) \\
\hline & & $\begin{array}{l}\text { Focus groups with local government representatives, } \\
\text { private sector actors and NGOs }\end{array}$ & 4 focus group (average of 8 participants in each) \\
\hline & & Site visits & \\
\hline & & Interviews with local government representatives & 3 interviews \\
\hline & & Objective 2: Co-create actions to mitigate climate c & change-related risks \\
\hline & & $\begin{array}{l}\text { Community-led capacity building workshops on } \\
\text { urban planning and citizen participation }\end{array}$ & 5 workshops (around 12 participants in each) \\
\hline & & $\begin{array}{l}\text { Workshops with community members on planning } \\
\text { tools and guidelines }\end{array}$ & 4 workshops (around 12 participants in each) \\
\hline & & $\begin{array}{l}\text { Presentation and validation of research findings and } \\
\text { action co-creation workshops with community } \\
\text { members, government rep resentatives, technical } \\
\text { experts and academia }\end{array}$ & 3 worshops (around 20 participants in each) \\
\hline & & $\begin{array}{l}\text { Preparation of educational infographic materials and } \\
\text { dissemination of research findings via social media }\end{array}$ & \\
\hline
\end{tabular}

across stakeholders, and the potential actions and solutions that could be agreed at the neighbourhood scale and later replicated across wider urban areas.

\subsection{Co-produced strategies for managing landslide risk in Medellín, Colombia}

An estimated 44,600 households within informal communities are exposed to the risk of landslides in the Medellín Metropolitan Area (Smith et al. 2020a). This number is expected to rise by at least 13,000 by 2030 (URBAM \& Harvard Design School 2012). The risk to inhabitants of these areas created by informal development practices became clear in 1987, when a landslide killed over 500 people in the low-income community of Villatina, substantially contributing to the estimated 784 deaths of low-income residents due landslides in Medellín over the last eighty years (O'Shea 2014). Despite the increased awareness of landslide risk caused by this event and the subsequent plan by the city administration to relocate parts of informal communities, local residents resisted relocation. This resistance evidenced a lack of trust in institutions, fuelled by a perception of double standards towards informally settled areas, with a refusal of city authorities to invest in risk mitigation infrastructure in these areas, contrasting with a willingness to build different types of infrastructure for the benefit of either the state or private companies. This distrust was also heightened by the possible influence of armed groups behind much of the informal land allocation.

\section{Research phase 1: initial pilot study community}

Initial research in Medellín focused on the development of co-produced solutions to monitor and mitigate landslide risk in informal communities at the urban-rural city edge (Smith et al. 2020a, 2020b, 2021). The research took place in the Pinares de Oriente neighbourhood, within Comuna 8, one of the low-income districts located high above the city in the north-eastern sector, where largely self-built communities 
have grown on steep slopes. In this neighbourhood, 180 households occupy 1.52 hectares of land, with 80 per cent of these having arrived following displacement due to the internal armed conflict in Colombia. The community straddles the notional urban edge according to the city's development plan, with the area north of the boundary exposed to high and non-mitigatable risk of landslides, according to the classification by the local planning authority. A seasonal stream that runs down the steep hillside disappears under the self-built houses, and there is generally very poor management of water runoff and drainage. As a result, many homes are exposed to the risk of landslides, exacerbated by poor water management and increasingly frequent high-intensity rainfall events driven by climate change (Aristizábal Giraldo et al. 2020).

The pilot study in Pinares de Oriente was led by a multidisciplinary team of researchers, including expertise from sociology, planning and slum upgrading, geotechnical and environmental engineering, as well as architecture and construction. This collaboration allowed for a structured dialogue between academics, local government, and informal urban communities, with the overall aim of exploring the scope for, and acceptability of, landslide risk-reduction strategies from the community and state perspectives. The research objectives were to (a) investigate the perceptions of risk and landslide risk among the community and public-sector organisations; (b) pilot participatory monitoring and mitigation strategies in the case study community; and (c) explore the potential for negotiated strategic landslide risk management between the community and public sector actors.

This research phase involved around seventy households, participating through focus groups, interviews, and workshops (Table 1; Medellín, Phase 1). A series of interviews with households were carried out to understand their perceptions of landslide risk, which was initially denied by local residents, due to fear of eviction. Through the project, the community's stance shifted from denying risk to admitting concern, especially during heavy rain. Through engagement with the community, trust was built between the research team and those involved from the local neighbourhood, which led to the achieved openness and willingness to engage in participatory monitoring and mitigation of risk.

Through a survey of the community and the hillside above it, transect walks together with members of the community, and a participatory mapping exercise, fourteen critical points for monitoring were identified, mainly in relation to water courses and embankments, as well as underbuilds below houses. Community volunteers agreed to monitor the selected critical points, to which aim the research team prepared a simple guidance manual. Each point was monitored by a pair of volunteers, who agreed to take photographs at those points on a regular basis, following the guidance, and to send the photographs to a WhatsApp group set up for each critical point. 
The research team also studied the factors impacting landslide risk to identify key mitigation works that could be undertaken by the community using appropriate technical solutions. This mitigation focused on the risk of small landslides within the community, rather than large-scale land movement that would require major engineering - or even relocation. The mitigation works focused on managing rainwater infiltration (a major factor in triggering landslides on the hillsides surrounding Medellín) and interventions were aimed around shared spaces, to ensure benefit for the whole community. The mitigation work was structured around a range of geographical scales and the corresponding levels of responsibility based on landownership around the intervention areas: a) community groups focused on the spaces around common access pathways (which are the responsibility of the local authority); b) groups of homeowners focused on spaces around groups of houses, where often inaccessible space is created due to informal construction; and c) individual homeowners focused on their own dwellings. The objective of these works was to channel rainwater towards the lower areas of the community, which are serviced by a municipality-owned drainage system, adding a fourth scale of responsibility and connecting the interventions across the community to the public network.

Regarding the use of smart technology, the research identified that an indispensable aspect of the success of the community-based monitoring methodology was having designated community leaders on the ground who motivated and encouraged residents to continue uploading digital photographs to the WhatsApp groups. The leaders sent messages on a regular basis via WhatsApp, strengthening participation and thanking people when they posted or added a photograph. Whilst digital technology helped to connect the research team with the community and facilitated a methodology for monitoring with precision, the social connections in situ remained fundamental for the successful application of the technology.

The research found that (1) community-based monitoring of landslide risk can be effective, but requires an ongoing and close link between the participating residents and the research team; (2) there is a need for local researchers and community leaders who are able to visit the area regularly and discuss the practicalities of data collection with the participants, as this provides 'a face' on the ground; (3) it is necessary to share with participants how the information is used and analysed across the involved national and international academic institutions to build trust; and (4) although the researchers and community members agreed upon the scale and ambition of the monitoring points, it proved to be challenging for community volunteers to cover all of these points on a regular basis, with some critical points receiving much lower attention than others, depending on the availability and interest of those undertaking the monitoring exercise (Smith et al. 2020b). In terms of capacity building, rooted in the experiences and approach of the research project, the local NGO ConVivamos 
created a Hillside Neighbourhood School (Escuela de Barrios de Ladera) at the wider scale of Comuna 8 , in collaboration with community leaders. The school was opened to all residents and focused on sharing knowledge around landslide risks, as well as monitoring, mitigation, and adaptation actions.

This initial example of community-based monitoring of landslide risk in Medellín raised awareness among the community of the importance of appropriate management of water drainage for risk reduction. In addition, the research process promoted local understanding of the factors responsible for landslide risk and the importance of community-level monitoring the environment. The research led to better informed residents in regards to appropriate mitigation actions that can be taken by and within the community with guidance from academic institutions, and this knowledge exchange is being sustained by the Hillside Neighbourhood School.

\section{Research phase 2: expansion of refined methodology to two additional communities}

The initial action-research experience in Pinares de Oriente was expanded to two further communities in Medellín (Table 1; Medellín, Phase 2) with a similar exposure to landslide risk due to their location on steep slopes, high above the city in the northeast sector. The aim of this research was to apply a refined methodology to neighbourhoods with different histories and community characteristics, to explore the potential for transferring this approach to different socio-economic and political contexts within the same city (Smith et al. 2020b, 2021). The settlements chosen for this phase of the research included El Pacífico (in Comuna 8), a dense and consolidated neighbourhood, and Carpinelo 2 (in Comuna 1), a more recently settled and much less consolidated community (see Smith et al. 2020b for further details).

Engagement with these additional communities began through negotiations facilitated by local NGOs, which determined the process and agreements for the co-production of knowledge. Research in each area was then conducted following a similar structure to that in Pinares de Oriente, including: i) understanding local perceptions of risk through interviews with community and government stakeholders; ii) implementing participatory monitoring strategies, via selecting critical points with community researchers, who then regularly uploaded photos to WhatsApp groups; and iii) facilitating agreements between local community members, NGOs, and city authorities around pathways forward for risk reduction. Key refinements to the initial research methodology, based on lessons learned from the action-research in Pinares, included more extensive training on monitoring practices for community volunteers, along with fewer critical monitoring points (see Table 1), to increase engagement and volunteer retention (Smith et al. 2020b). In addition, administration of the WhatsApp groups, including a weekly top-up of mobile phone data, was 
conducted locally by a community leader and academic researcher based in Comuna 8 , to encourage regular participation. These measures resulted in more consistent participation and therefore more systematic data collection (Smith et al. 2020b). Another key change to the action-research methodology was conducting regular workshops with community volunteers to jointly analyse the incoming data and ensure co-production of knowledge.

Although funding was not available for risk mitigation interventions within these two additional communities, possible future interventions were jointly identified by community members and the research team (Smith et al. 2021). Stakeholder mapping was also conducted to provide the communities with a departure point for future actions to be agreed. A key conclusion from research phases 1 and 2 was that landslide risk mitigation in these communities in the north-east sector of Medellín is intimately connected with drainage, as well as with pedestrian (and in parts limited vehicular) circulation pathways through the neighbourhoods (Smith et al. 2021). The research therefore highlighted that landslide risk management at the neighbourhood level in these areas is intrinsically linked with the urban infrastructure, demonstrating the scope for the co-production of risk mitigation infrastructure in the built environment.

\section{Research phase 3: linking community-based water and risk management with institutional plans and programmes}

The initial research phases in Medellín highlighted the importance of integrated risk and water management to reduce vulnerability in the informal communities of the north-east sector of the city. Our ongoing research in Medellin is therefore focusing on the co-production and testing of appropriate infrastructure solutions that engage with national and local investment programmes for neighbourhood improvement. The research is exploring the development and implementation of co-produced water-related and risk management solutions within wider spatial planning and housing-related policies in three new case study neighbourhoods: El Faro (Comuna 8), Bello Oriente, and San José la Cima 2 (the latter both in Comuna 3).

The research is providing a framework for co-created water management infrastructure, identifying responsibilities across different stakeholders: that is, at the family/household level, within groups of neighbouring houses, with the community network at the neighbourhood level, and institutional responsibility for public infrastructure. This is being carried out through a series of workshops and focus groups within the framework of a 'Laboratory of appropriate technologies for the strengthening of community autonomy in water and risk', integrating a disciplinary dialogue between environmental, technical, and social knowledge within a comprehensive approach linking water infrastructure and risk management with enhancing 
community agency and action. Preliminary diagnostic activities have identified that integrating climate change adaptation within a long-term planning vision is a strategic priority both within community organisation agendas and within institutional policies and programmes. This synergy has opened opportunities for establishing a 'dialogue of knowledges' between community members and local government, with the potential to shift the balance of power in risk management in informal areas of Medellín towards increased community agency, through co-producing innovative and sustainable solutions to water-related risk management.

\subsection{Understanding and mitigating climate-change-related risks in Puebla, Mexico}

Rapid urbanisation around the city of Puebla has created a sprawling metropolitan area, which is increasingly encroaching on neighbouring communities, affecting both the social and the environmental fabric. Increased demand for water for residential and industrial use, combined with deforestation and land-use change which have reduced aquifer recharge, threaten the viability of community wells. In addition, surface water flows such as rivers and streams are highly polluted due to poorly regulated discharge from urban areas and insufficient water treatment from industry (e.g., Casiano Flores \& Bressers 2015). In parallel, climate change has been accompanied by a significant reduction in overall precipitation in central Mexico, driving increasing water scarcity, while very heavy rainfall events have increased (Groisman et al. 2005), promoting flash flooding.

Research phase 1: identifying climate-change-related challenges and possible 'smart city' adaptation strategies through an interactive dialogue between stakeholders

Our initial research in the municipality of San Andrés Cholula focused on understanding the impacts of climate change in low-income, urban-rural edge communities affected by the expanding urban fabric. The city of Puebla is one of the fastest growing municipalities in Mexico. Between 1980 and 2010, San Andrés Cholula experienced a greater rate of urban growth (4.6 per cent) than the Puebla city centre (2.1 per cent) (OECD 2013), effected through a large-scale urban development plan. Through implementing an interactive dialogue between community members, public sector organisations, NGOs and other stakeholders, the research aimed to identify climate-change-related challenges at the local level and provide a framework for the agreement of possible 'smart' solutions based on the experiences of local people. This approach contrasts with a recent unsuccessful top-down attempt to implement 'smart city' technologies in one of the municipality's neighbourhoods, Santa María Tonantzintla, which discounted the experiences and knowledge of the targeted urban communities and was rejected by residents (Wattenbarger 2018). 
Over twelve months, the research team engaged in qualitative data collection through focus groups, workshops, site visits, and semi-structured interviews with government authorities, local urban and rural communities, civil organisations, and academic actors (Table 1). To understand local stakeholder perceptions around climate-change-related risks, a series of focus groups were held with local community members, including representatives from six districts in the municipality - Santa María Tonantzintla, San Francisco Acatepec, Cabecera de San Andrés Cholula, San Bernardino Tlaxcalancingo, San Antonio Cacalotepec, and San Rafael Comac - who were all members of a grassroots movement named 'Cholultecas United in Resistance' (Cholultecas Unidos en Resistencia), created in reaction to recent urban development decisions that failed to consult and consider local needs. Focus groups were also conducted with actors from the public, private, and third sectors, including environment and urban planning researchers, local public officials, entrepreneurs, civil organisations, and NGOs such as Oxfam, UNDP (United Nations Development Programme), and Ayuda en Acción (Help through Action, an NGO has worked across Mexico over the past twenty years helping to defend the rights and dignity of vulnerable communities). During these participatory processes, discussions took place around the history of the community, and the challenges and vulnerabilities in terms of climate-changerelated risks. An important challenge perceived by local communities was in relation to the 2018 San Andrés Cholula Urban Development Plan, due to the impact of urban expansion in reducing agricultural land and displacing local communities due to higher taxation and a fragmented urban structure.

Overall, the research identified three overarching challenges experienced by the local communities:

- Water Management: The recent urbanisation and population growth are affecting the recharge of the aquifer from which most people extract water from wells for household use. In parallel, new housing developments are increasing the demand for water. Water security risks therefore exist due to aquifer overexploitation, as well as changes in agricultural practices and inadequate waste management from housing and industry, which are observed to be polluting the soil and the water. In addition, participants identified that urban development and 'progress' linked to paving and construction have increased the risks of flooding.

- Urban Expansion: Rapid urbanisation has occurred in the absence of territorial planning, driving the loss of agricultural land, traditional housing, a loss of identity, a lack of neighbourhood cohesion, a lack of inclusion of green areas, and deforestation.

- Pollution: Poor waste management and the use of chemical fertilisers have led to the contamination of soil and water; rubbish in the streets is contributing to flooding by blocking drains; and air pollution is affecting residents, connected 
to congestion and poor-quality public transport. In particular, communities linked the use of chemical fertilisers with education and behavioural issues.

Although government-enforced regulation was viewed as important, the need for knowledge acquisition around risks was strongly expressed by local communities. Specifically, communities wanted greater knowledge of the impact on the natural environment of adaptation strategies they may put in place to tackle climate-changerelated risks, and raised the need to collect and share information within their community and with public sector organisations. Education, in terms of receiving as well as collecting data, was therefore viewed as a priority, to inform communities' everyday decision-making and practice in relation to the environment. Moreover, residents valued better understanding of the negative influence that their actions may have on the natural environment and welcomed knowledge of potential strategies, such as recycling, managing food waste, and sustainable crops, to mitigate these negative impacts. As a transition from traditional agricultural land use towards urban land use is occurring in this area, more sustainable agricultural practices were identified as a priority, due to a concern that the development of crops could worsen climate change impacts and perhaps increase flooding. A particular threat highlighted for this area was the removal of trees without considering soil conditions, the potential for absorbing rainwater, and buffering the negative effects of chemicals used on crops. Sustainable waste management was also identified as key in terms of knowledge development.

Another challenge identified by the communities was related to coping with the impacts of high-intensity rainfall events before, during, and after they occur. For example, receiving timely warnings of heavy rainfall was viewed as critical to mitigate damage from flooding. Although most members of these urban communities have Wi-Fi access and use data on their mobile phones, a specific communication tool is not in place to provide warnings and trigger specific actions before and during a heavy rainfall event. Opportunities for action in these areas therefore relate to education and knowledge exchange programmes, infrastructure systems for water collection and drainage, water filters, and community-informed technological solutions.

Through understanding local perceptions around risks, and the actions being taken at the community and institutional levels, the research sought to create opportunities for knowledge exchange between communities, and technical, professional, and government actors, in order to agree and co-create actions focused on tackling climate-change-related risks. The research explored short-, medium-, and long-term impacts of the identified risks at the household level, in the public space and in the productive (agricultural) space, within an integrated framework considering different geographical scales, which was rooted in jointly determining the different levels of responsibility when developing solutions. The findings of the research in relation to 
climate-change-related impacts perceived at the local level were presented and validated through three multi-stakeholder workshops where possible actions for reducing these risks were identified and agreed. In addition, as the Urban Development Plan was perceived as a key factor increasing risk, the research team helped to engage communities in the consultation process for the Plan, promoting a platform for negotiation.

The research identified a range of challenges in relation to climate change within this complex area interlocking both urban and rural conditions. The project provided a framework for knowledge development and exchange, engaging and promoting community-level action. At the same time, the research generated a platform for dialogue and reflection between local residents and authorities, mediated by academic representatives, on the basis of which agreements were reached to incorporate community needs into the Urban Development and Environmental Management Plans. The knowledge developed and actions agreed at the neighbourhood level were upscaled by small resident groups leading projects to recover old water channels and ditches, plant trees, and transform their own houses to contribute to rainwater capture. In collaboration with institutions, these efforts could be scaled up to achieve wider impact across the region.

\section{Research phase 2: co-creating water security in the Upper Atoyac River basin}

Communities in San Andrés Cholula perceive that urban development policies and programmes have been an important driver of water pollution, water scarcity, and inadequate water management. Through generating trust and commitment from local organisations, government institutions, and communities, our initial research identified a knowledge gap around actions and policies that could, in combination with technological solutions promoting knowledge exchange and communication, reduce the negative impacts of climate-change-related risks. This research demonstrated that 'smart' decision-making should not only be rooted in public participation but also in informed public action with a long-term vision.

Importantly, the initial research highlighted that water management and governance at a range of geographic scales-from the household level, to the neighbourhood and municipality levels - is key to addressing climate-change-related risks in the area, motivating a broader range of stakeholder consultations in urban and rural communities over the wider river basin relevant to the city of Puebla, the Upper Atoyac River basin (UARB). Qualitative and quantitative data collection has contributed to developing water security indicators incorporating the aspects of scarcity, quality, and vulnerability. In addition, hydrological modelling is allowing us to project the future trajectory of these indicators under regional climate change scenarios, 
with the aim of identifying critical areas of water scarcity, and co-developing and testing strategies for improved long-term water security in the UARB.

\section{Discussion}

\subsection{Importance of local perceptions of climate-change-related risks to inform risk management strategies}

Despite the growth and mainstreaming of participative approaches to risk management (Maskrey 2011), these have had limited impact at the global scale. This has been attributed to a lack of understanding of underlying drivers of risk, such as uncontrolled urbanisation, land-use change, or the growth of informal settlements. It is therefore essential to review, conceptualise, and implement action around the social dimension of risk management. In addition, many risk reduction initiatives implemented at the local scale by NGOs and other extra-community actors lack local ownership and tend to end when the programme ends, undermining sustainability (Maskrey 2011). In order to achieve long-term action and change, it is essential to understand the willingness and capability of stakeholders to participate in locally based initiatives, as well as the geographical scale of actions that are needed, and the responsibilities (that is, powers) of different stakeholders within strategies to reduce risk.

In addition, due to considerable uncertainty around the regional impacts of climate change, the lay knowledge of people who experience local impacts is of crucial importance for guiding risk management. Moreover, household coping strategies are an essential component of risk management, but developing the full potential of these strategies requires community empowerment and, often, technical assistance. Our action-research approach engaging with local communities in Medellín and Puebla has helped to understand the complexity of the risks associated with poor water management, which results in increased vulnerability to climate-change-related risks (for example, exposure to landslides, flooding, and/or water scarcity, depending on the setting). In addition, the research demonstrated that urban communities are able to identify their own vulnerabilities in the context of climate change impacts, and are willing and capable of co-producing risk management solutions to build local resilience to the impacts of climate change, when working in collaboration with local organisations and academia. Furthermore, these experiences have shown that community engagement should occur at all stages of a project, from planning to execution and maintenance, allowing local people to take ownership of the proposed actions.

In particular, our research in informal and low-income areas at the urban-rural edge in cities of Latin America has shown that more integrated participation of local 
people in risk and water management in a territory leads to 1) a more accurate understanding of the impacts of climate change and development decisions on daily lives and livelihoods, and 2) data collection at finer spatial and temporal scales than is often possible for the institutions traditionally responsible for risk management. In the context of increasing the adaptive capacity of vulnerable urban communities to climate-change-related risks, these experiences highlight the need to first understand risks as experienced by people living in a given setting, and to explore means to connect government actions with community knowledge, to enable the identification and agreement of sustainable solutions, and potential upscaling of mitigation and adaptation strategies.

\subsection{Establishing a 'dialogue of knowledges' to identify technically appropriate and culturally accepted risk management strategies}

In order to achieve a greater degree of risk reduction, it is important to expand actions from the local scale to address structural issues on a greater scale, which are commonly beyond the reach of local actors (Maskrey 1984, 2011). It is therefore essential to explore the scope for 'co-production' at different geographical scales and across different organisations, to understand priorities, responsibilities, and roles. Our research has explored these alternative forms of engagement between local communities and government institutions for risk management, beyond merely consultative forms of public participation. Co-produced solutions piloted through our collaborative research demonstrate the need for stronger involvement from both community and state institutions in the development of more informed and integrated risk management strategies, across different levels of responsibility (for example, individuals, communities, and municipal governments) and the corresponding geographical scales (that is, individual dwellings, groups of dwellings, neighbourhoods, municipalities, and river basins). Academia and local NGOs can play a significant role in facilitating these interactions and establishing channels that allow opportunities for negotiation and agreement, particularly in engaging a wider range of stakeholders in risk management and risk governance.

Our research in both Medellín and Puebla demonstrates that increasing the adaptive capacity of informal and low-income urban communities in the face of climate change entails empowering them to use their knowledge and resources to understand and monitor risk. Establishing a means for dialogue and knowledge exchange can then support effective interactions between stakeholders: for example, communities and public sector authorities responsible for decision-making and for the development and implementation of risk management programmes. Our experiences in Medellín and Puebla showed that integrated risk management strategies that 
place local knowledge on a level platform with other forms of knowledge can increase community agency by empowering local people to participate in decision-making, allowing a shift in the power dynamics at the local and neighbourhood scales. This shift can enable both technically appropriate and culturally accepted, and therefore more sustainable, solutions to be reached, as well as opportunities for upscaling actions, opening a pathway beyond simply building resilience at the local level, towards adaptive transformation in the framework of Pelling (2011).

\subsection{The role of 'smart' technologies in building resilience and adaptive capacity}

Our experiences in Medellín and Puebla motivate reflections on the vulnerability of low-income and informal urban communities, climate change adaptation, and the role of 'smart' technology in risk management. Our research demonstrates that connecting these concepts through a qualitative action-research programme can bridge interdisciplinary divides and provide novel insights for adapting to climate-changerelated risks. The research in Medellín demonstrated that 'smart' technology can serve as a channel for communication that facilitates a regular, continuous dialogue between stakeholders (in this case, communities and technical experts), which is especially effective when community members are empowered to act as equal stakeholders participating in data analysis and decision-making. The research in Puebla showed that communities need easily accessible information and communication tools to enable them to share observations of their environment and identify appropriate adaptation actions. Furthermore, governments require detailed knowledge of local impacts to guide policies and programmes that truly meet community needs. Our research therefore motivates greater interaction between communities and public sector organisations in the creation and implementation of 'smart' technologies intended to facilitate risk management and sustainable urban development. Examples of valuable technological solutions are those that provide two-way (communities and authorities) access to data on local resources, risks, and adaptation actions, through hosting community managed maps, discussion forums, infographics, and interactive visualisation tools.

Our research shows that local citizens are able to monitor their environment at a finer resolution than the authorities responsible for risk management. However, these actors do not easily influence decision-making. Our action-research has demonstrated the value of easily accessible information and communication tools able to link top-down, 'traditional' forms of governance with bottom-up initiatives, facilitating knowledge exchange around potential climate change and urban development impacts and strategies. 'Smart' technological approaches that facilitate this dialogue hold the potential to harness local knowledge, resources, and participation, as well as technical 
and professional knowledge that tends to be compartmentalised within privileged sectors of society. On the basis of our experiences in Medellín and Puebla, we argue that co-producing and co-managing appropriate 'smart' technologies therefore represents an important step to catalysing sustainable knowledge exchange between stakeholders, and empowering communities through shared responsibility to adapt to climate-change-related (and other) risks.

\section{Concluding remarks}

Adaptation solutions should be relevant and tailored to local climate change impacts, which in urban environments are intimately connected to development policies and strategies. Our research has highlighted that communities are able to identify solutions if horizontal flows of knowledge are enabled and relationships of trust are established. If supported by suitable technologies, the knowledge generated by actionresearch approaches, such as those in Medellín and Puebla described in this paper, can spread beyond the local level and beyond the timescale of these projects, allowing continuity in data collection and dialogue. Nevertheless, solutions may be difficult to identify at the necessary scale without financial support and policy enforcement. Context-specific and appropriate technologies therefore need to be identified, and the participation of local residents as well as local (and national, where necessary) governments is needed to co-produce and deliver appropriate adaptation and mitigation strategies. This is where we believe that 'smart' technology can serve as the connection bringing communities, their experiences, needs, and knowledge, together with the required political influence, financial support, and scaled policy development. We therefore advocate for the development and implementation of strategies that use 'smart' technology, when these are co-produced and co-managed between diverse stakeholders, to help establish trust and continuity of data collection, dialogue, and risk management beyond political cycles.

With respect to the challenges facing low-income and self-built communities in the Global South exposed to climate-change-related risks, our work has contributed to strengthening organisational and technical capacities at the local level, developing methodologies with the potential to increase community autonomy and question traditional forms of governance. Within this perspective, our work has promoted the decentralisation of the management of 'common goods', recognising stakeholder organisational capacities and interests, as well as conflicts, in risk governance. This approach encourages social cohesion and communal appropriation of the developed solutions and infrastructure, promoting the expansion of the margins of local democracy. Therefore, co-produced actions to tackle climate-change-related risks, could be 
linked with a higher level of autonomy and agency at the community level when making decisions around urban and resources management. Vulnerable communities can be empowered by interactions and dialogue between different stakeholders. Our research has provided evidence that informal urban communities are able to monitor their territory and implement and use 'smart' technology to mitigate climate change risks if (1) these technologies allow bottom-up participatory adaptation measures, and (2) training and support from a multidisciplinary team including representatives from public sector organisations as well as academic researchers and technical experts is provided. Future research should explore the potential for these strategies and techniques to be rolled out at a wider scale with community-based researchers, leveraging training and communication programmes, establishing mechanisms replicable to different cities, and creating society-wide change by rebalancing community/institutional power relations - using co-produced 'smart' technology that incorporates community knowledge and experience, and simultaneously helps to create and influence climate-change-related local and national policies.

\section{Acknowledgements}

In Medellín, the pilot project in Pinares de Oriente in 2016-17 ('Resilience or resistance? Negotiated mitigation of landslide risks in informal settlements in Medellín') was funded by NERC/ESRC/AHRC, led by Heriot-Watt University. The follow-on research in El Pacífico and Carpinelo 2 in 2017-19 ('Co-production of Landslide Risk Management Strategies Through Community Infrastructure Development in Latin American Cities') was funded by the British Academy, led by Heriot-Watt University. The current research in El Faro, Bello Oriente, and San José la Cima 2 ('Exploring the development and implementation of co-produced solutions and infrastructures for water management towards the adaptation of risk related to climate change at the intersection of urban-rural areas in Medellín'; 2020-22) is funded by the British Academy, led by the University of Edinburgh. Local universities (Universidad Nacional de Colombia, Universidad de Antioquia), local community leaders, local NGOs, and municipalities participated in this research. The initial research in Puebla in 2019-21 ('Developing collaborative smart city solutions to manage adaptation and monitoring climate change related risks in Mexico') was funded by a Newton Institutional Links grant, and the follow-on research in the wider Upper Atoyac River Basin ('Climate Change Policies for People: Implementing Co-Developed Water Governance and Security in the Upper Atoyac River Basin, Puebla'; 2020-22) is funded by a Newton Impact grant. Local universities (Universidad Ibero-Americana de Puebla, Universidad de las Americas Puebla), local community leaders and groups, and local government participated in this research. 


\section{References}

Aguilar-Barajas, I., Sisto, N.P., Ramirez, A.I. \& Magaña-Rueda, V. (2019), 'Building Urban Resilience and Knowledge Co-production in the Face of Weather Hazards: Flash Floods in the Monterrey Metropolitan Area (Mexico)', Environmental Science and Policy, 99(September): 37-47. https://doi.org/10.1016/j.envsci.2019.05.021

Albino, V., Berardi, U. \& Dangelico, R. (2015), 'Smart Cities: Definitions, Dimensions, Performance, and Initiatives', Journal of Urban Technology, 22(1): 3-21.

https://doi.org/10.1080/10630732.2014.942092

Alcaldía de Medellín (2020), Plan de Desarollo: Medellín Futuro 2020-2023. https://www.medellin.gov. co/irj/go/km/docs/pccdesign/medellin/Temas/PlanDesarrollo/Publicaciones/Shared\%20Content/ Documentos/2020/DocumentoFinal_PlanDesarrolloMedellin2020-2023_MedellinFuturo.pdf [accessed 17 September 2021].

Alcántara-Ayala, I., Garza Salinas, M., López García, A., Magaña Rueda, V., Oropeza Orozco, O., Puente Aguilar, S., Rodríguez Velázquez, D., Lucatello, S., Ruiz Rivera, N., Tena Núñez, R.A., Urzúa Venegas, M. \& Vázquez Rangel, G. (2019), 'Gestión Integral de Riesgo de Desastres en México: reflexiones, retos y propuestas de transformación de la política pública desde la academia', Investigaciones Geográficas, (98). https://doi.org/10.14350/rig.59784

Allen, A., Griffin, L. \& Johnson, C. (2017), Environmental Justice and Urban Resilience in the Global South (New York, Palgrave Macmillan). https://doi.org/10.1057/978-1-137-47354-7

Anderson, M.G. \& Holcombe, E. (2013), Community-based Landslide Risk Reduction: Managing Disasters in Small Steps (Washington, DC, The World Bank). https://doi.org/10.1596/978-0-8213-9456-4

Angelidou, M. (2014), 'Smart City Policies: A spatial Approach', Cities, 41(S1), S3-S11. https://doi.org/10.1016/j.cities.2014.06.007

Appleby, K. (2020), 'The Smartest Cities on Climate: What Can We Learn?', SmartCities World. https:// www.smartcitiesworld.net/opinions/opinions/the-smartest-cities-on-climate-what-can-we-learn [accessed 8 October 2020].

Aristizábal Giraldo, E.V., García Aristizábal, E., Marín Sánchez, R., Gómez Cardona, F. \& Guzmán Martínez, J.C. (2020), 'Rainfall-intensity Effect on Landslide Hazard Assessment Due to Climate Change in North-western Colombian Andes', Revista Facultad de Ingeniería, Universidad De Antioquia. https://doi.org/10.17533/udea.redin.20201215

Asamblea Nacional Constituyente (2021), 'Constitución Política de Colombia. Vigente, con las modificaciones. Última actualización 09/09/2021’. https://leyes.co/constitucion/download.htm [accessed 17 September 2021].

Baker, J.L. (2013), 'Climate Change, Disaster Risk, and the Urban Poor: Cities Building Resilience for a Changing World', Choice Reviews Online, 50(5). https://doi.org/10.5860/CHOICE.50-2769

Barrionuevo, J.M., Berrone, P. \& Ricart Costa, J.E. (2012), 'Smart Cities, Sustainable Progress: Opportunities for Urban Development', IESE Insight, (14), 50-7. https://doi.org/10.15581/002.ART-2152

Bibri, S.E. \& Krogstie, J. (2017), 'Smart Sustainable Cities of the Future: An Extensive Interdisciplinary Literature Review', Sustainable Cities and Society, 31: 183-212. https://doi.org/10.1016/j.scs.2017.02.016

Borquez, R., Aldunce, P. \& Adler, C. (2017), 'Resilience to Climate Change: From Theory to Practice Through Co-production of Knowledge in Chile', Sustainability Science, 12(1): 163-76. https://doi.org/10.1007/s11625-016-0400-6

Brugnach, M., Craps, M. \& Dewulf, A.R.P.J. (2017), 'Including Indigenous Peoples in Climate Change Mitigation: Addressing Issues of Scale, Knowledge and Power', Climatic Change, 140(1): 19-32. https://doi.org/10.1007/s10584-014-1280-3 
Calthorpe, P. (2011), Urbanism in the Age of Climate Change (Washington, DC, Island Press/Center for Resource Economics). https://doi.org/10.5822/978-1-61091-005-7

Cámara de Diputados (2021), 'Constitución Política de los Estados Unidos de México. Texto vigente, Ultima reforma publicada 28-05-2021'. http://www.diputados.gob.mx/LeyesBiblio/pdf_mov/Constitucion_Politica.pdf

CARE (2014), 'Participatory Monitoring, Evaluation, Reflection and Learning for Community-based Adaptation: PMERL a Revised Manual for Local Practitioners' (London, CARE International UK).

Casiano Flores, C. \& Bressers, J.T. (2015), 'Changes Without Changes: The Puebla's Alto Atoyac Sub-basin Case In Mexico', Water Governance, 2015(1/2): 12-16.

Chourabi, H., Nam, T., Walker, S., Gil-Garcia, J.R., Mellouli, S., Nahon, K., Pardo, T.A. \& Scholl, H.J. (2012), 'Understanding Smart Cities: An Integrative Framework', in Proceedings of the Annual Hawaii International Conference on System Sciences, 2289-97. https://doi.org/10.1109/HICSS.2012.615

Davies, M., Guenther, B., Leavy, J., Mitchell, T. \& Tanner, T. (2009), 'Climate Change Adaptation, Disaster Risk Reduction and Social Protection: Complementary Roles in Agriculture and Rural Growth?', IDS Working Papers, 2009(320). https://doi.org/10.1111/j.2040-0209.2009.00320_2.x

de Lange, M. \& de Waal, M. (2013), 'Owning the City: New Media and Citizen Engagement in Urban Design', First Monday, 18(11). https://doi.org/10.5210/fm.v18i11.4954

Durán Vargas, L.R. (2011), 'La reducción del riesgo de desastres: ¿un callejón con salida?', Revista EIRD informa —Las Américas, 17. https://www.eird.org/esp/revista/no_17_2010/art9.html

Ekanayake, S.B. (1990), 'Rural Pedagogy: A Grassroots Approach to Rural Development', Prospects, 20(1): 115-27. https://doi.org/10.1007/BF02195434

Ekström, M., Kuruppu, N., Wilby, R.L., Fowler, H.J., Chiew, F.H.S., Dessai, S. \& Young, W.J. (2013), 'Examination of Climate Risk Using a Modified Uncertainty Matrix Framework-Applications in the Water Sector', Global Environmental Change, 23(1): 115-29. https://doi.org/10.1016/j.gloenvcha.2012.11.003

Etkin, D. \& Ho, E. (2007), 'Climate Change: Perceptions and Discourses of Risk', Journal of Risk Research, 10(5): 623-41. https://doi.org/10.1080/13669870701281462

Fraser, A. (2017), 'The Missing Politics of Urban Vulnerability: The State and the Co-production of Climate Risk', Environment and Planning A, 49: 2835-52. https://doi.org/10.1177/0308518X17732341

Frigerio, S., Schenato, L., Bossi, G., Mantovani, M., Marcato, G. \& Pasuto, A. (2018), 'Hands-on Experience of Crowdsourcing for Flood Risks: An Android Mobile Application Tested in Frederikssund, Denmark', International Journal of Environmental Research and Public Health, 15: 1926. https://doi.org/10.3390/ijerph15091926

Garcia Ferrari, S., Bain, A.A. \& Crane De Narváez, S. (2021), 'Drivers, Opportunities, and Challenges for Integrated Resource Co-management and Sustainable Development in Galapagos', Frontiers in Sustainable Cities, 3: 29. https://doi.org/10.3389/frsc.2021.666559

Garcia Ferrari, S., Morales, E.R. \& Bain, A.A. 'City Profile: Mexico City. Challenges Around Spatial and Environmental Planning from a Risk Management Perspective', Cities, under review.

Greenfield, A. (2013), 'Against the Smart City', Urban Omnibus. https://urbanomnibus.net/2013/10/against-the-smart-city/ [accessed 5 November 2020].

Groisman, P.Y., Knight, R.W., Easterling, D.R., Karl, T.R., Hegerl, G.C. \& Razuvaev, V.N. (2005), 'Trends in Intense Precipitation in the Climate Record', Journal of Climate, 18(9): 1326-50. https://doi.org/10.1175/JCLI3339.1

Hallegatte, S., Rentschler, J. \& Walsh, B. (2018), 'Building Back Better-Achieving Resilience Through Stronger, Faster, and More Inclusive Post-disaster Reconstruction', report 47 (Washington, DC, The World Bank). https://doi.org/10.1596/29867 
Hardoy, J. \& Romero Lankao, P. (2011), 'Latin American Cities and Climate Change: Challenges and Options to Mitigation and Adaptation Responses', Current Opinion in Environmental Sustainability, 3(3): 158-63. https://doi.org/10.1016/j.cosust.2011.01.004

Hill, A.C. \& Martinez-Diaz, L. (2020), 'Get the Data and Make Them Usable', in A.C. Hill \& L. Martinez-Diaz (eds) Building a Resilient Tomorrow: How to Prepare for the Coming Climate Disruption (Oxford, Oxford University Press), 98-115. https://doi.org/10.1093/oso/9780190909345.003.0006

Hollands, R.G. (2015), 'Critical Interventions Into the Corporate Smart City', Cambridge Journal of Regions, Economy and Society, 8(1): 61-77. https://doi.org/10.1093/cjres/rsu011

IPCC (2007), 'Climate Change 2007: Impacts, Adaptation and Vulnerability', in Contribution of Working Group II to the Fourth Assessment Report of the Intergovernmental Panel on Climate Change (Cambridge, Cambridge University Press). https://doi.org/10.1016/B978-008044910-4.00250-9

Kitchin, R. (2014), 'The Real-time City? Big Data and Smart Urbanism', GeoJournal, 79: 1-14. https://doi.org/10.1007/s10708-013-9516-8

Lavell, A. (2003), 'Local Level Risk Management: Concepts and Experience in Central America. The Latin American Social Science Faculty and the Network for the Social Study of Disaster Prevention in Latin America-LA RED', paper presented at the Disaster Preparedness and Mitigation Summit, 21-23 November, 2002, New Delhi, India. https://www.desenredando.org/public/articulos/2003/llrmceca/llrmceca_abr-24-2003.pdf

López Meneses, D.H. \& Cañadas, S.H. (2018), 'Altos de la Estancia: An Applied Project of Risk Governance in Colombia', in W. Leal Filho \& L.E. Freitas (eds) Climate Change Adaptation in Latin America: Managing Vulnerability, Fostering Resilience (Cham, Springer), 477-99. https://doi.org/10.1007/978-3-319-56946-8_29

Luque-Ayala, A. \& Marvin, S. (2015), 'Developing a Critical Understanding of Smart Urbanism?', Urban Studies, 52(12): 2105-16. https://doi.org/10.1177/0042098015577319

Lytras, M.D. \& Visvizi, A. (2020), 'Sustainable Smart Cities and Smart Villages Research. Rethinking Security, Safety, Well-being and Happiness', Sustainability, 12(1): 215. https://doi.org/10.3390/books978-3-03928-219-7

Magrin, G.O., Marengo, J.A., Boulanger, J.-P., Buckeridge, M.S., Castellanos, E., Poveda, G., Scarano, F.R. \& Vicuña, S. (2014), 'Central and South America', in V.R. Barros, C.B. Field, D.J. Dokken, M.D. Mastrandrea, K.J. Mach, T.E. Bilir, M. Chatterjee, K.L. Ebi, Y.O. Estrada, R.C. Genova, B. Girma, E.S. Kissel, A.N. Levy, S. MacCracken, P.R. Mastrandrea \& L.L. White (eds) Climate Change 2014: Impacts, Adaptation, and Vulnerability. Part B: Regional Aspects. Contribution of Working Group II to the Fifth Assessment Report of the Intergovernmental Panel on Climate Change (Cambridge, Cambridge University Press), 1499-536. https://doi.org/10.5860/CHOICE.45-5008

Maguire, B. \& Cartwright, S. (2008), 'Assessing a Community's Capacity to Manage Change: A Resilience Approach to Social Assessment' (Canberra, Bureau of Rural Science).

Maskrey, A. (1984), 'Community Based Disaster Mitigation', in Proceedings of the International Conference on Disaster Mitigation Program Implementation: Ocho Rios, Jamaica, 12-16 November (Blacksburg, VA, Virginia Polytechnic Institute and State University, Center for International Development Planning).

Maskrey, A. (1989), ‘Community Based Disaster Mitigation' (Oxford, OXFAM Publications).

Maskrey, A. (2011), 'Revisiting Community-based Disaster Risk Management', Environmental Hazards, 10(1): 42-52. https://doi.org/10.3763/ehaz.2011.0005

Mitlin, D. (2008), 'With and Beyond the State - Co-production as a Route to Political Influence, Power and Transformation for Grassroots Organizations', Environment and Urbanization, 20(2): 339-60. https://doi.org/10.1177/0956247808096117 
Mitlin, D. \& Bartlett, S. (2018), 'Editorial: Co-production-Key Ideas', Environment and Urbanization, 30(2): 355-66. https://doi.org/10.1177/0956247818791931

Moreno Pires, S., Magee, L. \& Holden, M. (2017), 'Learning from Community Indicators Movements: Towards a Citizen-powered Urban Data Revolution', Environment and Planning C: Politics and Space, 35(7): 1304-23. https://doi.org/10.1177/2399654417691512

Moser, C. \& Stein, A. (2011), 'A Methodological Guideline for Implementing Urban Participatory Climate Change Adaptation Appraisals', Environment and Urbanization, 22(2): 463-86. https://doi.org/10.1177/0956247811418739

Mustapha, K., Mcheick, H. \& Mellouli, S. (2016), 'Smart Cities and Resilience Plans: A Multi-agent Based Simulation for Extreme Event Rescuing', in J.R. Gil-Garcia, T.A. Pardo \& T. Nam (eds) Smarter as the New Urban Agenda: A Comprehensive View of the 21st CenturyCity (Cham, Springer International), 149-70. https://doi.org/10.1007/978-3-319-17620-8_8

OECD (2013), 'OECD Territorial Reviews: Puebla-Tlaxcala, Mexico 2013' (Paris, OECD Publishing). https://doi.org/10.1787/9789264203464-en.

O’Shea, C. (2014), 'Shifting Ground: Precarious Settlements and Geological Hazard in Medellin, Colombia', Landscape Architecture Frontiers, 2(4): 148-60.

Pandey, B. \& Okazaki, K. (n.d.), 'Community Based Disaster Management: Empowering Communities to Cope with Disaster Risk' (Nagoya, United Nations Centre for Regional Development).

PAOT (2019), 'Ley de Gestión Integral de Riesgos y Protección Civil de la Ciudad de México', Procuraduría Ambiental y del Ordenamiento Territorial. http://www.paot.org.mx/centro/leyes/ df/pdf/2021/LEY_GEST_RIESGO_PROTECC_CIVIL_CDMX_02_03_2021.pdf [accessed 21 June 2021].

Pelling, M. (2011), Adapting to Climate Change, from Resilience to Adaptation (New York, Routledge). https://doi.org/10.4324/9780203889046

Pelton J.N. \& Singh I.B. (2019), 'The Smart City: Build It and They Will Come', in Smart Cities of Today and Tomorrow (Cham, Copernicus). https://doi.org/10.1007/978-3-319-95822-4_14

Picon, A. (2015), Smart Cities: A Spatialised Intelligence (Chichester, John Wiley). https://doi.org/10.1002/9781119075615

Satterthwaite, D., Archer, D., Colenbrander, S., Dodman, D. \& Hardoy, J. (2017), 'Responding to Climate Change in Cities and in Their Informal Settlements and Economies', International Journal of Disaster Risk Reduction, 26(December), 1-6. https://doi.org/10.1016/j. ijdrr.2017.09.050

Smith, H., Coupé, F., Garcia Ferrari, S., Rivera, H. \& Mera, W.E.C. (2020a), 'Toward Negotiated Mitigation of Landslide Risks in Informal Settlements: Reflections from a Pilot Experience in Medellín, Colombia', Ecology and Society, 25(1): 19. https://doi.org/10.5751/ES-11337-250119

Smith, H., Garcia Ferrari, S., Medero, G., Rivera, H., Coupé, F., Caballero, H., Castro Mera, W.E., Aiko, A., Marinho, F. \& Ferreira, K. (2020b), 'Learning from Co-produced Landslide Risk Mitigation Strategies in Low Income Settlements in Medellin (Colombia) and Sao Paulo (Brazil)', in A. Ley, M. Ur Rahman \& J. Fokdal (eds) Housing and Human Settlements in a World of Change, Habitat International Series in International Urbanism, Volume 25 (Berlin, De Gruyter). https://doi.org/10.14361/9783839449424-013

Smith. H., Garcia Ferrari, S., Medero, M., Rivera, H., Coupé, F., Mejía Escalante, M., Castro Mera, W., Montoya Correa, C., Abiko, A. \& Marinho, F. (2021), 'Exploring Appropriate Sociotechnical Arrangements for the Co-production of Landslide Risk Management Strategies in Informal Neighbourhoods in Colombia and Brazil, International Journal of Urban Sustainable Development, https://doi.org/10.1080/19463138.2021.1872082

Stevenson, F. \& Petrescu, D. (2016), 'Co-producing Neighbourhood Resilience', Building Research and Information, 44(7): 695-702. https://doi.org/10.1080/09613218.2016.1213865

UN General Assembly (2015), 'Transforming Our World: The 2030 Agenda for Sustainable Development', 21 October 2015, A/RES/70/1. https://www.refworld.org/docid/57b6e3e44.html 
UN-Habitat (2011), 'Cities and Climate Change: Global Report on Human Settlements 2011'. https://unhabitat.org/global-report-on-human-settlements-2011-cities-and-climate-change; https://doi.org/10.4324/9781849776936

UNISDR (2015), 'Sendai Framework for Disaster Risk Reduction 2015-2030'. United Nations Office for Disaster Risk Reduction.

https://www.preventionweb.net/files/43291_spanishsendaiframeworkfordisasterri.pdf [accessed 17 September 2021].

United Nations (2021), The Sustainable Development Goals Report 2021 (New York, United Nations). https://unstats.un.org/sdgs/report/2021/The-Sustainable-Development-Goals-Report-2021.pdf [accessed 7 October 2021].

URBAM \& Harvard Design School (2012), Re Habitar La Ladera: Shifting Ground (Medellín, Universidad EAFIT).

van der Most, H., Asselman, N. \& Slager, K. (2018), 'Experiences in Developing and Applying Decision Support Systems for Strategic Flood Risk Managemen', International Journal of River Basin Management, 16(3), 371-8. https://doi.org/10.1080/15715124.2017.1411925

Watson, V. (2014), 'Co-production and Collaboration in Planning-The Difference', Planning Theory and Practice, 15(1): 62-76. https://doi.org/10.1080/14649357.2013.866266

Wattenbarger, M. (2018), 'The Mexican Town that Refused to Become a Smart City', The Guardian, 16 October. https://www.theguardian.com/cities/2018/oct/16/the-mexican-town-that-refused-tobecome-a-smart-city

White, J.M. (2016), 'Anticipatory Logics of the Smart City’s Global Imaginary', Urban Geography, 37(4): 572-89. https://doi.org/10.1080/02723638.2016.1139879

Wilches-Chaux, G. (1993), 'La Vulnerabilidad Global', in A. Maskrey (ed.) Los Desastres no son Naturales - LA RED (Bogotá, Tercer Mundo Editores), 11-44.

\section{Notes on the authors}

Soledad Garcia Ferrari, Edinburgh School of Architecture and Landscape Architecture, University of Edinburgh.

Corresponding author: s.garcia@ed.ac.uk

Katharina Kaesehage, Centre for Business, Climate Change and Sustainability, Business School, University of Edinburgh.

Stephanie Crane De Narvaez, Edinburgh School of Architecture and Landscape Architecture, University of Edinburgh.

Amelia A. Bain, Edinburgh School of Architecture and Landscape Architecture, University of Edinburgh.

To cite the article: Soledad Garcia Ferrari, Katharina Kaesehage, Stephanie Crane De Narvaez and Amelia A. Bain (2021), 'Adaptation strategies for people: mitigating climate-change-related risks in low-income and informal urban communities through co-production', Journal of the British Academy, 9(s9): 7-37.

DOI https://doi.org/10.5871/jba/009s9.007

Journal of the British Academy (ISSN 2052-7217) is published by

The British Academy, 10-11 Carlton House Terrace, London, SW1Y 5AH

www.thebritishacademy.ac.uk 
